\title{
AC 2009-1035: PROFESSIONAL LICENSING BOARDS: A COMPARISON OF REGISTRATION ACTS, CODES OF ETHICS, AND DISCIPLINARY ACTIONS
}

Salvatore Marsico, Pennsylvania State University, Wilkes-Barre 


\title{
Professional Licensing Boards: A Comparison of Registration Acts, Code of Ethics, and Disciplinary Actions
}

\begin{abstract}
The professional registration boards for engineering are created and operate under the laws of their respective jurisdictions. They are given the power to regulate the profession by establishing minimum criteria, to review candidates for registration, to address and resolve complaints against registered and unregistered persons who may have violated the statutes governing the profession. The power of these boards, in the United States, is vested in them through the police power of their respective states' constitutions. Addressing ethical issues impacting the profession is a central theme which runs throughout the required capstone course Professional Aspects of Land Surveying offered at Penn State University. In addressing these issues students, for first three weeks of the semester are engaged in reading, interpreting statutes, and researching case law with respect to registration laws, code of ethics, and the disciplinary actions taken by the licensing boards of a number of jurisdictions. It is the intent of this article to present a compilation of the similarities and differences of the laws regulating registration and in light of the ethical issues arising from the practice of engineering the article will compare and contrast disciplinary actions taken by these boards pursuant to a filing of a formal complaint.
\end{abstract}




\section{Introduction}

The Surveying Engineering Program offered by Penn State University at its Wilkes-Barre Campus requires a capstone course, Professional Aspects of Land Surveying (SU 471), that exposes the student to a variety of topics including registration laws. As an introduction to registration laws the students are required to know the rules that govern their profession. Using this as a guidepost they are then required to gather the registration laws for all of the jurisdictions of the United States. This affords them the opportunity to recognize similarities and differences amongst the jurisdictions. In addition, for the first time, students were required to search for disciplinary actions taken by registration board of the jurisdictions of the United States to recognize similarities and differences. It is the information gathered by the students that I wish to share and provide some insight as to the actions taken by the boards and to see if their actions are consistent among their peers.

\section{Governing Rules}

The states are autonomous institutions that develop regulations that obstesbily are aimed at protecting the citizenry. Under our federalist system states and territories are given power to regulate by the United States Consitution's $5^{\text {th }}$ Amendment ${ }^{1}$ police power through the $14^{\text {th }}$ Amendment $^{2}$. Also, each of the states govern their citizenry through their respective state constitutions $^{3}$ which virtually mimic the federal constitution. Through their exercise of the police power they enact legislation to protect the welfare of the public: "The Constitution devotes the domain to union, to justice, to defense, to welfare, and to liberty. ${ }^{4 \prime}$

One of the ways to protect the public is officially recognize that a profession is distinct from a vocation and then regulate the profession through regulatory agencies such as registration boards. It was not until the early 1990's that Florida courts distinguished between a vocation and profession $^{5}$. This court stated that a profession requires a minimum education level of a baccalaureate degree. Statutes are enabling legislations which permit the administrative agencies to create documents to promote the concept of the legislation. That is, professional registration boards are the administrative agencies granted the right to develop rules and regulations to promote the intent of the legislation:

"The Mission of the Minnesota Board of Architecture, Engineering, Land Surveying, Landscape Architecture, Geoscience and Interior Design is to protect the public health, safety and welfare by:

- Ensuring that those entering the professional practice of architecture, engineering, land surveying, landscape architecture, geology, soil science, or those using the title of certified interior designer, meet standards of competency by means of education, examination and experience;

- Establishing standards of practice for those licensed to practice;

- Requiring anyone practicing or offering to practice architecture, engineering, land surveying, landscape architecture, geology or soil science be licensed and continue to maintain professional competence;

- Requiring anyone using the title of certified interior designer be certified and continue to maintain professional competence;

- Enforcing the laws, rules and standards governing the practice of architecture, engineering, land surveying, landscape architecture, geology, and soil science, or the use of the title certified interior designer, in Minnesota in a fair, expeditious and consistent manner." 
In essence the registration boards are the frontline persons or the neighborhood police: "In order to safeguard property and public welfare ${ }^{6} . "$ As with any policing agency they are both a proactive as well as a reactive organization. As a proactive organization they develop rules such as the requirements to register as a licensee, develop codes of ethics to guide the actions of a professional:

"rules of professional conduct are promulgated and shall be binding upon every person holding a license as a professional engineer or land surveyor and on all partnerships or corporations or other legal entities authorized to offer or perform engineering and/or land surveying services in Connecticut,",

and to promulgate them through paper as well as digital forms. As a reactive organization, the boards are charged with investigating cases involving violations of regulations as well as serve a judicial function of deciding the initial fate of the licensee:

"Subd. 2. Legal action. (a) When necessary to prevent the unauthorized practice of architecture, engineering, land surveying, landscape architecture, geoscience, or the unauthorized use of the title certified interior designer, or a violation of a statute, rule, or order that the board has issued or is empowered to enforce, the board, or the complaint committee if authorized by the board, may bring an action in the name of the state" 8

One interesting area of analysis is that which focuses on those cases that have been appealed to the appropriate judicial branch within the jurisdiction. The analysis here is unlike the cases presented by organizations such as $\mathrm{NSPE}^{9}$ or other state registration boards which present cases that have not been appealed to the courts of law. In most instances the licensee does not appeal the verdicts of the registration boards to the courts for a variety of reasons. Thus, there a many more disciplinary actions that are not appealed and consequently recorded as final actions.

\section{Licensing Statutes}

In some instances, such as Alabama, a distinction is made between graduates from accredited and nonaccredited institutions.:

"1. Graduation in an approved engineering curriculum plus four years experience....

2. Graduation in an unapproved engineering curriculum plus six years experience.... ${ }^{10}$ Whereas, other states require: "(i) graduation from an approved engineering curriculum of four or more years. ${ }^{11}$ Each jurisdiction exercises autonomy and works with the registration boards to develop statutes which meet their specific needs and make provisions for those coming from other jurisdictions to either practice permanently or temporarily:

"(A) The state board of registration for professional engineers and surveyors may authorize a temporary registration for an individual who has filed with the board an application for a temporary registration and has paid the required fee. The temporary registration continues only for the time the board requires for consideration of the application for registration, provided a person is legally qualified to practice that profession in the person's own state in which the requirements and qualifications of registration are not lower than those specified in this chapter. ${ }^{12}$

Within the licensing statutes are listed particular sanctions for various offenses, the board "shall have the power to place any land surveyor on probation or to revoke or suspend any registration under the provisions of sections $81-8,108$ to $81-8,127$, when the land surveyor has 
been found guilty of any of the following practices: (1) fraud or deceit in obtaining a registration; (2) negligence or incompetency in the performance of his or her duties; or (3) misconduct in the performance of his or her duties. ${ }^{13}$

\section{Code of Ethics}

Professional organizations such as NSPE as well as NSPS promote their respective professions by interacting with the registration boards to establish rules and promote their efficacy. The NSPE Preamble lays out what the expectation level is for the practitioner:

"engineers are expected to exhibit the highest standards of honesty and integrity. Engineering has a direct and vital impact on the quality of life for all people.

Accordingly, the services provided by engineers require honesty, impartiality, fairness, and equity, and must be dedicated to the protection of the public health, safety, and welfare. Engineers must perform under a standard of professional behavior that requires adherence to the highest principles of ethical conduct."

The NSPE further sets out the context to exercise professional duties, whereby the engineer shall:

1. Hold paramount the safety, health, and welfare of the public.

2. Perform services only in areas of their competence.

3. Issue public statements only in an objective and truthful manner.

4. Act for each employer or client as faithful agents or trustees.

5. Avoid deceptive acts.

6. Conduct themselves honorably, responsibly, ethically, and lawfully so as to enhance the honor, reputation, and usefulness of the profession.

These words are echoed in one form another in all of the regulations of the all states. For Pennsylvania:

It shall be considered unprofessional and inconsistent with honorable and dignified bearing for any professional engineer, professional land surveyor or professional geologist:

(1) To act for his client or employer in professional matters otherwise than as a faithful agent or trustee, or to accept any remuneration other than his stated recompense for services rendered.

(2) To attempt to injure falsely or maliciously, directly or indirectly, the professional reputation, prospects or business of anyone.

(3) To attempt to supplant another engineer, land surveyor or geologist after definite steps have been taken toward his employment.

(4) To compete with another engineer, land surveyor or geologist for employment by the use of unethical practices.

(5) To review the work of another engineer, land surveyor or geologist for the same client, except with the knowledge of such engineer, land surveyor or geologist, or unless the connection of such engineer, land surveyor or geologist with the work has terminated.

(6) To attempt to obtain or render technical services or assistance without fair and just compensation commensurate with the services rendered: Provided, however, the donation of such services to a civic, charitable, religious or eleemosynary organization shall not be deemed a violation.

(7) To advertise in self-laudatory language, or in any other manner, derogatory to the dignity of the profession. 
(8) To attempt to practice in any field of engineering, land surveying or geology in which the registrant is not proficient.

(9) To use or permit the use of his professional seal on work over which he was not in responsible charge.

10) To aid or abet any person in the practice of engineering, land surveying or geology not in accordance with the provision of this act or prior laws. ${ }^{14}$

\section{Board Actions}

The actions by the boards vary by the type of infraction committed by the professional. It is interesting to analyze results of board actions taken for similar infractions and note the results. To initiate an action against a licensee a complaint must filed by filling out the appropriate form $^{15}$

"If you believe the practice or the service provided by a licensee or registrant of the above-named boards or commissions to be unethical, immoral, below an acceptable standard of practice or out of the scope of the profession. ${ }^{16}$

By far the most extensive and recent file of disciplinary actions is maintained by the State of Wisconsin ${ }^{17}$. In at least one jurisdiction, West Virginia the registration board for surveying has not record any infractions requiring sanctions for the last 10 years. In another, the Massachusetts board publishes only recent infractions and dispositions (as of 2007) ${ }^{18}$. Any additional information must be requested under the freedom of information act of Massachusetts ${ }^{19}$. In many instances the infractions are subject to minor fines but can be a loss of license when the infraction is of a grave nature and it's the desire of the board to make sure that this licensee understands that they violated a fundamental underpinning of the profession.

\begin{tabular}{|c|c|c|c|}
\hline Year & Infraction & Jurisdiction & Board Action \\
\hline 2008 & $\begin{array}{l}\text { Use of seal and PE } \\
\text { designation under expired } \\
\text { license }\end{array}$ & $\begin{array}{l}\text { PA } \\
\text { http://www.dos.state.pa.us/ } \\
\text { bpoa }\end{array}$ & Fine $\$ 2000$ \\
\hline 2006 & $\begin{array}{l}\text { Use of seal when license } \\
\text { was expired }\end{array}$ & PA & $\begin{array}{l}\text { Public reprimand, } \\
\text { and } \$ 1000 \text { fine }\end{array}$ \\
\hline 2006 & Guilty of 4 felonies & $\mathrm{PA}$ & License revoked \\
\hline 2005 & $\begin{array}{l}\text { Misuse of Professional } \\
\text { Seal }\end{array}$ & PA & $\begin{array}{l}\$ 250 \text { fine, } \\
\text { suspension for } 60 \\
\text { days, and } \\
\text { required to take } \\
\text { an ethics course }\end{array}$ \\
\hline 2008 & $\begin{array}{l}\text { Unprofessional conduct for } \\
\text { sealing documents over } \\
\text { which he had no personal } \\
\text { supervision }\end{array}$ & $\begin{array}{l}\text { Utah } \\
\text { http://www.dopl.utah.gov/ }\end{array}$ & Public reprimand \\
\hline 2007 & $\begin{array}{l}\text { Unprofessional Conduct for } \\
\text { failure to submit timely plat }\end{array}$ & Utah & 1 year probation \\
\hline 2000 & $\begin{array}{l}\text { a)Professional Misconduct } \\
\text { b) Moral Turpitude }\end{array}$ & $\begin{array}{l}\text { New Jersey } \\
\text { http://www.nj.gov }\end{array}$ & License revoked \\
\hline
\end{tabular}




\begin{tabular}{|c|c|c|c|}
\hline 2000 & $\begin{array}{l}\text { Professional Misconduct in } \\
\text { another state }\end{array}$ & New Jersey & License revoked \\
\hline 2007 & $\begin{array}{l}\text { Drafted a Boundary Line } \\
\text { Agreement, Did not follow } \\
\text { client instructions, and } \\
\text { expressed an opinion } \\
\text { without having reviewed all } \\
\text { facts }\end{array}$ & Maine & $\begin{array}{l}\text { Warning, Letter } \\
\text { of Guidance, and } \\
\$ 1400 \text { in costs }\end{array}$ \\
\hline 2006 & Drafted and easement & New Jersey & Fine $\$ 500$ \\
\hline 2009 & $\begin{array}{l}\text { Operating without a license } \\
\text { from } 2002-2006\end{array}$ & $\begin{array}{l}\text { Wisconsin } \\
\text { http://drl.wi.gov/dept/decisi } \\
\text { ons/ }\end{array}$ & $\begin{array}{l}\text { Voluntary } \\
\text { surrender of } \\
\text { license }\end{array}$ \\
\hline 2009 & $\begin{array}{l}\text { Failure to use reasonable } \\
\text { care and competence when } \\
\text { providing a professional } \\
\text { service (unprofessional } \\
\text { conduct) }\end{array}$ & Wisconsin & $\begin{array}{l}15 \text { day suspension } \\
\text { and court costs of } \\
\$ 600\end{array}$ \\
\hline 2008 & $\begin{array}{l}\text { Failure to adhere to many } \\
\text { professional standards } \\
\text { (unprofessional conduct) }\end{array}$ & Wisconsin & $\begin{array}{l}\text { Licensed revoked } \\
\text { and } \$ 9250.00 \\
\text { court costs }\end{array}$ \\
\hline 2008 & Operating without a license & $\begin{array}{l}\text { Washington } \\
\text { http://www.dol.wa.gov/abo } \\
\text { ut/disciplinary/disciplinary } \\
\text { el.html }\end{array}$ & $\begin{array}{l}\text { Cease and desist } \\
\text { and pay } \$ 1000\end{array}$ \\
\hline 2008 & $\begin{array}{l}\text { Failed to meet standard of } \\
\text { care }\end{array}$ & Washington & $\begin{array}{l}\text { Probation } 1 \mathrm{yr}- \\
\text { pay } \$ 500 \text { fine }\end{array}$ \\
\hline 2005 & $\begin{array}{l}\text { 1)Practice with expired } \\
\text { license } \\
\text { 2) felony conviction }\end{array}$ & $\begin{array}{l}\text { Vermont } \\
\text { http://vtprofessionals.org }\end{array}$ & $\begin{array}{l}\text { Suspension for } 30 \\
\text { days and } \\
\text { continuing if } \\
\text { probation is } \\
\text { violated, re- } \\
\text { certify all work }\end{array}$ \\
\hline 2008 & Failure to obtain CE credits & http://www.maine.gov & $\begin{array}{l}\text { Reprimand and } \\
\$ 750 \text { fine }\end{array}$ \\
\hline
\end{tabular}

\section{Cases}

In the case of Amsden v New Hampshire Board of Land Surveyors and its individual members a local licensed professional takes on an association with an unlicensed surveyor. The state permits an unlicensed surveyor to gain field experience under the supervision of a license surveyor: "Amsden was licensed as a land surveyor in 1969. Six years later, he became associated with Tyrone Hunter, an unlicensed (but practicing) land surveyor. Such an association was not uncommon; like apprenticeships in other fields, the praxis allowed newcomers to the profession

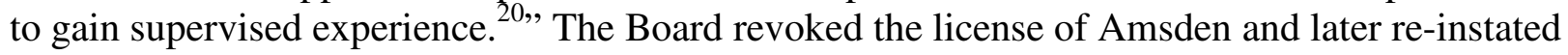
the license unconditionally after a thorough investigation of the association between Amsden and the unlicensed surveyor. 
The State of Washington courts highlight an interesting case whereby an individual writes a letter on behalf of his neighbors to a local government agency expressing concerns over an upcoming project ${ }^{21}$. In the letter he refers to himself as an engineer and later a complaint is filed with the licensing board with respect to is practice of engineering with a license. He agrees that he is not licensed to practice engineering in any jurisdiction and that he is employed by a manufacturing company and has "engineer" in his job title. The board sanctions him for the unlicensed practice of engineering. He appeals the board's decision to the courts and claims that his First Amendment rights to free speech were violated in that he was speaking out about a public project. The court reasoned that his comments were not sanctioned but his right to make the comments as an engineer expressing an opinion was being sanctioned because only licensed engineers could express an opinion on behalf of clients.

The Mississippi Licensing Board took action against an engineer after granting him a license by comity, whereby, the applicant was registered in another state and met the Mississippi requirements to register as a PE. Subsequently, the Board re-evaluated the application and decided it made an error and revoked the license. The PE filed suit against the Board and the Court reasoned that the Board must follow state statutes as opposed to agency regulation when the two are in conflict. In this case, the Board interpreted the exam requirement to mean the EIT and the Practice exam. The Court made it perfectly clear that the statute is silent on how many exams must be passed and therefore must rescind the revocation and re-instate this licensee. ${ }^{22}$

A corporation advertises in the local yellow pages that it is a consulting engineering firm and holds itself out to the clients as consulting engineers. The state board of Connecticut brings a disciplinary action against the corporation and orders a cease and desist order. The corporation appeals the case to district court on the grounds of the First Amendment Freedom of Speech more specifically Protected Speech. This court's analysis was that the corporation's work was not protected speech but rather engineering analysis that was conveyed to clients and subject to the licensing statutes of the state. ${ }^{23}$

\section{Conclusion}

The states and territories do a great job at setting out and promulgating the rules but it is the state organizations through their meetings and conferences that do excellent work at maintaining high standards and promoting those to the rank and file. Although the specific language for professional registration and disciplinary actions vary among the states, the overall the actions taken by the State Boards for similar infractions are consistent across the jurisdictions. Furthermore, the courts across the jurisdictions are also consistent with their analysis and disposition of cases. The goal of these boards is to promote the profession and to protect the public from those professionals that take unnecessary risk that may harm the public. 
${ }^{1}$ U.S. Const $5^{\text {th }}$ Amendment

${ }^{2}$ U.S. Const $14^{\text {th }}$ Amendment

${ }^{3} \mathrm{http}: / / \mathrm{www}$. legis.state.pa.us

${ }^{4}$ Id.

${ }^{5}$ In re Pierce

${ }^{6}$ PROFESSIONAL LAND SURVEYORS' ACT (Business and Professions Code $§ 8708$

${ }^{7}$ Sec. 20-300-12. Code of ethics

${ }^{8}$ M. S. A. § 326.02, et.seq.

${ }^{9}$ producing advisory opinions on ethics cases. http://www.asee.org/conferences/annual/2009/Call-forPapers.cfm\#author

${ }^{10}$ AL STAT $\$ 34-11-4$

${ }^{11} 63$ P.S. § 151.2

${ }^{12}$ OH ST $§ 4733.18$

${ }^{13}$ Nebraska Code $81-8,124$

${ }^{14} 63$ P.S. 151

${ }^{15}$ Statement of Complaint Form (State Dependent)

${ }^{16} \mathrm{http}: / /$ www.state.pa.us

${ }^{17} \mathrm{http} / / / \mathrm{www}$.wisconsin.gov

${ }^{18} \mathrm{http} / / / \mathrm{www} / \mathrm{mass} . \mathrm{gov}$

${ }^{19}$ MGL c. 66, et seq.

${ }^{20}$ Amsden v Moran, 904 F.2d 748 (1990)

${ }^{21}$ Knight v. Browne, 2007 U.S. Dist. LEXIS 46843 (2007)

${ }^{22}$ Leland v Mississippi State Board of Professional Registration, 841 F. Supp. 192 (1993)

${ }^{23}$ Obeda v CONNECTICUT BOARD OF REGISTRATION FOR PROFESSIONAL ENGINEERS AND LAND SURVEYORS, 570 F. Supp. 1007 (1983) 